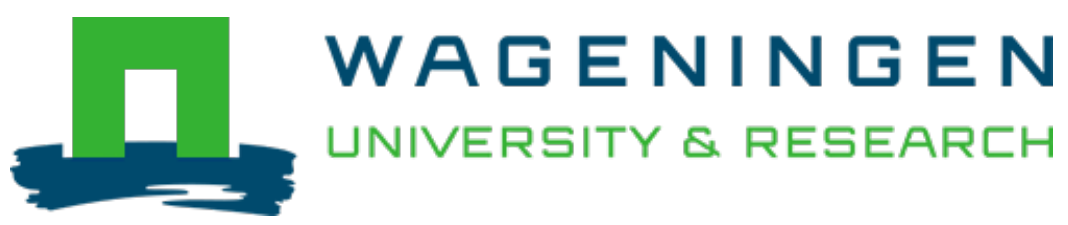

\title{
Functional yeasts and molds in fermented foods and beverages
}

Fermented Foods and Beverages of the World

Aidoo, K.E.; Nout, M.J.R.

https://www.taylorfrancis.com/chapters/edit/10.1201/EBK1420094954-8/functional-yeasts-molds-fermented-foodsbeverages-ko-aidoo-robert-nout

This publication is made publicly available in the institutional repository of Wageningen University and Research, under the terms of article $25 \mathrm{fa}$ of the Dutch Copyright Act, also known as the Amendment Taverne. This has been done with explicit consent by the author.

Article $25 \mathrm{fa}$ states that the author of a short scientific work funded either wholly or partially by Dutch public funds is entitled to make that work publicly available for no consideration following a reasonable period of time after the work was first published, provided that clear reference is made to the source of the first publication of the work.

This publication is distributed under The Association of Universities in the Netherlands (VSNU) 'Article $25 \mathrm{fa}$ implementation' project. In this project research outputs of researchers employed by Dutch Universities that comply with the legal requirements of Article $25 \mathrm{fa}$ of the Dutch Copyright Act are distributed online and free of cost or other barriers in institutional repositories. Research outputs are distributed six months after their first online publication in the original published version and with proper attribution to the source of the original publication.

You are permitted to download and use the publication for personal purposes. All rights remain with the author(s) and / or copyright owner(s) of this work. Any use of the publication or parts of it other than authorised under article $25 \mathrm{fa}$ of the Dutch Copyright act is prohibited. Wageningen University \& Research and the author(s) of this publication shall not be held responsible or liable for any damages resulting from your (re)use of this publication.

For questions regarding the public availability of this publication please contact openscience.library@wur.nl 
Functional Yeasts and Molds in Fermented Foods and Beverages

\author{
Kofi E. Aidoo and M. J. Robert Nout
}

\title{
CONTENTS
}

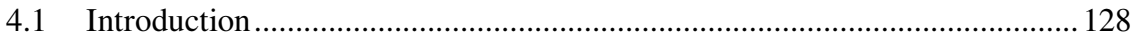

4.2 Functional Roles of Yeasts and Molds in Fermented Foods of the World..... 129

4.2.1 Fermented Foods of Asian Origin........................................................ 129

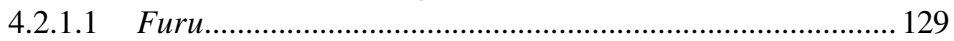

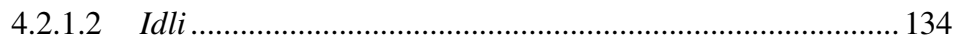

4.2.1.3 Ragi and Men ......................................................... 135

4.2.2 Fermented Foods of Australasian Origin ....................................... 136

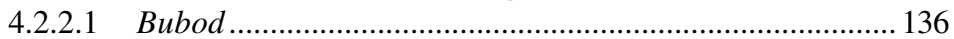

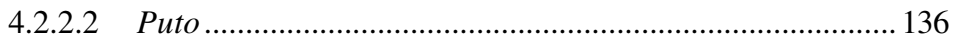

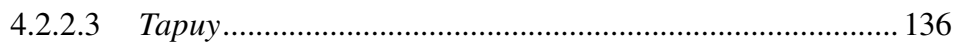

4.2.3 Fermented Foods of African Origin............................................ 137

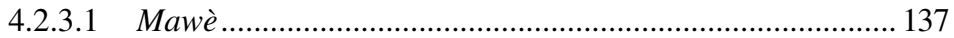

4.2.3.2 Tchoukoutou.................................................................. 138

4.2.3.3 Kachasu ....................................................................... 138

4.2.4 Fermented Foods of European Origin............................................. 139

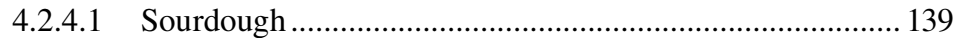

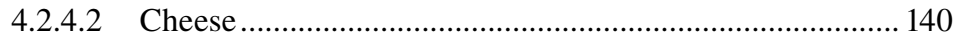

4.2.4.3 Fermented Meats.............................................................. 140

4.2.5 Fermented Foods of Middle East Origin......................................... 141

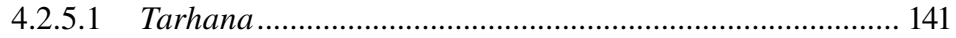

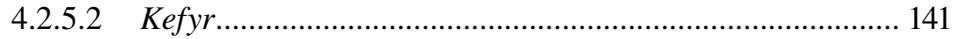

4.2.5.3 Koumiss.......................................................................... 141

4.2.6 Fermented Foods of Latin American Origin .................................. 142

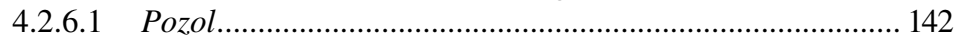

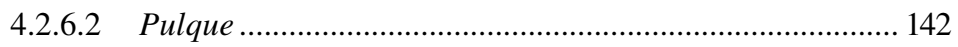

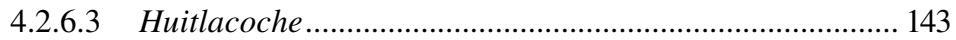

4.3 Benefits of, and Some Problems Associated with,

Fungal-Fermented Foods ................................................................. 144

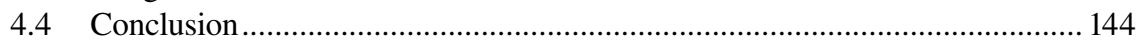

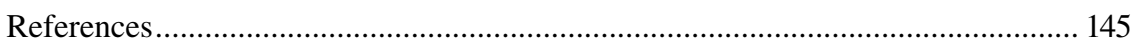




\subsection{Introduction}

Fermented foods and beverages are produced as a result of the activities of microorganisms, principally yeasts, molds, and bacteria. Fungi (yeasts and molds) play a major role in traditional fermented foods that have long histories. Today, some of these fermented products have achieved industrial development and are produced on a large scale as a result of the application of modern technology, automation in production engineering, and biotechnology in the genetic manipulation of functional yeasts and molds. Yeasts play vital roles in the production of many traditional

\section{TABLE 4.1}

Main Functional Properties of Fungi in Fermented Foods

\begin{tabular}{|c|c|c|}
\hline Genera & Species & Functional Properties \\
\hline \multicolumn{3}{|l|}{ Fungi } \\
\hline \multicolumn{3}{|l|}{ Zygomycetes } \\
\hline Actinomucor & A. elegans, A. taiwanesis & \multirow{8}{*}{$\begin{array}{l}\text { Production of enzymes: } \\
\text { Carbohydrases- } \alpha \text {-amylase, } \\
\text { amyloglucosidase, maltase, } \\
\text { invertase, pectinase, } \\
\beta \text {-galactosidase, cellulase, } \\
\text { hemi-cellulase, and pentosan- } \\
\text { degrading enzymes; acid and } \\
\text { alkaline proteases; lipases; } \\
\text { anti-nutritional properties, } \\
\text { e.g., degradation of phytic acid, } \\
\text { thus improving bioavailability } \\
\text { of minerals }\end{array}$} \\
\hline Amylomyces & A. rouxii & \\
\hline Mucor & $\begin{array}{l}\text { M. circinelloides, } M . \text { rouxii, } \\
\text { M. indicus }\end{array}$ & \\
\hline Rhizopus & $\begin{array}{l}\text { R. microsporus var. chinensis, } \\
\text { R. oligosporus, } R \text {. oryzae, } \\
\text { R. stolonifer }\end{array}$ & \\
\hline Ascomycetes & & \\
\hline Monascus & M. purpureus, $M$. ruber, $M$. anka & \\
\hline Neurospora & N. sitophila, $N$. intermedia & \\
\hline Aspergillus & $\begin{array}{l}\text { A. oryzae, A. sojae, A. glaucus, } \\
\text { A. melleus, A. repens, A. candidus, } \\
\text { A. tamarii, A. usamii, A. niger }\end{array}$ & \\
\hline \multicolumn{3}{|l|}{ Eurotiomycetes } \\
\hline Penicillium & P. glaucus, $P$. roqueforti & \\
\hline \multicolumn{3}{|l|}{ Basidiomycetes } \\
\hline Ustilago & U. maydis & \\
\hline \multicolumn{3}{|l|}{ Yeasts } \\
\hline Brettanomyces & B. anomalus & \multirow{11}{*}{$\begin{array}{l}\text { Production of amylolytic } \\
\text { enzymes, ethanol, aldehydes, } \\
\text { isobutanol, isoamyl alcohol, } \\
\text { esters, fusel oils, flavors } \\
\text { compounds, 4-hydroxy-2 (or } \\
\text { 5)-ethyl-5 (or 2)-methyl-3(2H)- } \\
\text { furanone (HEMF), phenolic } \\
\text { compounds-4-ethylguaiacol } \\
\text { and 4-ethylphenol contribute to } \\
\text { aroma }\end{array}$} \\
\hline Candida & C. javanica, C. famata & \\
\hline Geotrichum & G. candidum & \\
\hline Hansenula & H. anomala & \\
\hline Pichia & P. burtonii & \\
\hline Rhodotorula & Rh. glutinis & \\
\hline Saccharomycopsis & Sm. fibuliger & \\
\hline Saccharomyces & $\begin{array}{l}\text { S. cerevisiae, S. dairensis, } \\
\text { S. globosus, S. kluyveri, S. saké }\end{array}$ & \\
\hline Torulopsis & Tor. versatilis & \\
\hline Trichosporon & Tr. Pullulans & \\
\hline Zygosaccharomyces & Zygos. rouxii, Zygos. sojae. & \\
\hline
\end{tabular}

Source: Adapted from Nout, M.J.R. and Aidoo, K.E., Asian fungal fermented food, in The Mycota, ed. Osiewacz, H.D., Springer-Verlag, New York, 2002, pp. 23-47. 
fermented foods and beverages across the world (Aidoo et al. 2006) that signify the food culture of the regions and the community (Tamang and Fleet 2009). About 21 major genera with several species of functional yeasts have been reported from fermented foods and beverages that include Brettanomyces (its perfect stage, Dekkera), Candida, Cryptococcus, Debaryomyces, Galactomyces, Geotrichum, Hansenula, Hanseniaspora (its asexual counterpart Kloeckera), Hyphopichia, Kluyveromyces, Metschnikowia, Pichia, Rhodotorula, Saccharomyces, Saccharomycodes, Saccharomycopsis, Schizosaccharomyces, Torulopsis, Trichosporon, Yarrowia, and Zygosaccharomyces (Kurtzman and Fell 1998, Pretorius 2000, Romano et al. 2006, Tamang and Fleet 2009). Molds in fermented foods and beverages are relatively limited, and include the genera Actinomucor, Mucor, Rhizopus, Amylomyces, Monascus, Neurospora, Aspergillus, and Penicillium (Hesseltine 1983, 1991, Samson 1993, Nout and Aidoo 2002).

This chapter deals with the main functional yeasts and molds in some of the major fermented foods of the world. Some of the benefits and problems associated with fungal fermented food are also discussed. The major functional properties of yeasts and molds in fermented foods are summarized in Table 4.1. Fermented foods and beverages of the world and their respective functional yeasts and molds are presented in Table 4.2 .

\subsection{Functional Roles of Yeasts and Molds in Fermented Foods of the World}

\subsubsection{Fermented Foods of Asian Origin}

\subsubsection{Furu}

Furu, also known as sufu, is a flavor-rich Chinese fermented soybean product (Figure 4.1) (Han et al. 2001). According to the region and local preferences, there are different shapes, colors, and flavors of furu. The principle of preparation is as follows: first, soymilk is made by soaking, grinding, and extracting soybeans; next, the soy protein is coagulated by the addition of salt, and the resulting tofu is collected and pressed to a sheet of firm consistency. Tofu is cut into dices that are spray-inoculated with fungal spores (Actinomucor elegans and/or A. taiwanensis) and incubated at about $20^{\circ} \mathrm{C}-25^{\circ} \mathrm{C}$ to allow profuse mycelial growth (pehtze); the pehtze is matured during several months in brine that also contains coloring, spices, etc. The final product has a soft, spreadable consistency. It contains high levels of free amino acids, particularly glutamic acid (Han et al. 2004), and free fatty acids, and it is a very popular item at the breakfast table to go with rice, vegetables, etc. The key function of Actinomucor is its production of proteolytic and lipolytic enzymes. Studies on the modifications of soy protein before and during maturation have shown that at an early stage, the large protein molecules are decomposed to oligopeptides, followed by the gradual release of peptides, free amino acids, and nitrogenous degradation products such as $\mathrm{NH}_{3}$. The optimum temperature for the production of extracellular enzymes by Actinomucor is $25^{\circ} \mathrm{C}$; thus the production of furu during hot summers is problematic. It was found that "tropical" molds such as Rhizopus spp. can be used in the production of an acceptable furu as an alternative (Han et al. 2003). 


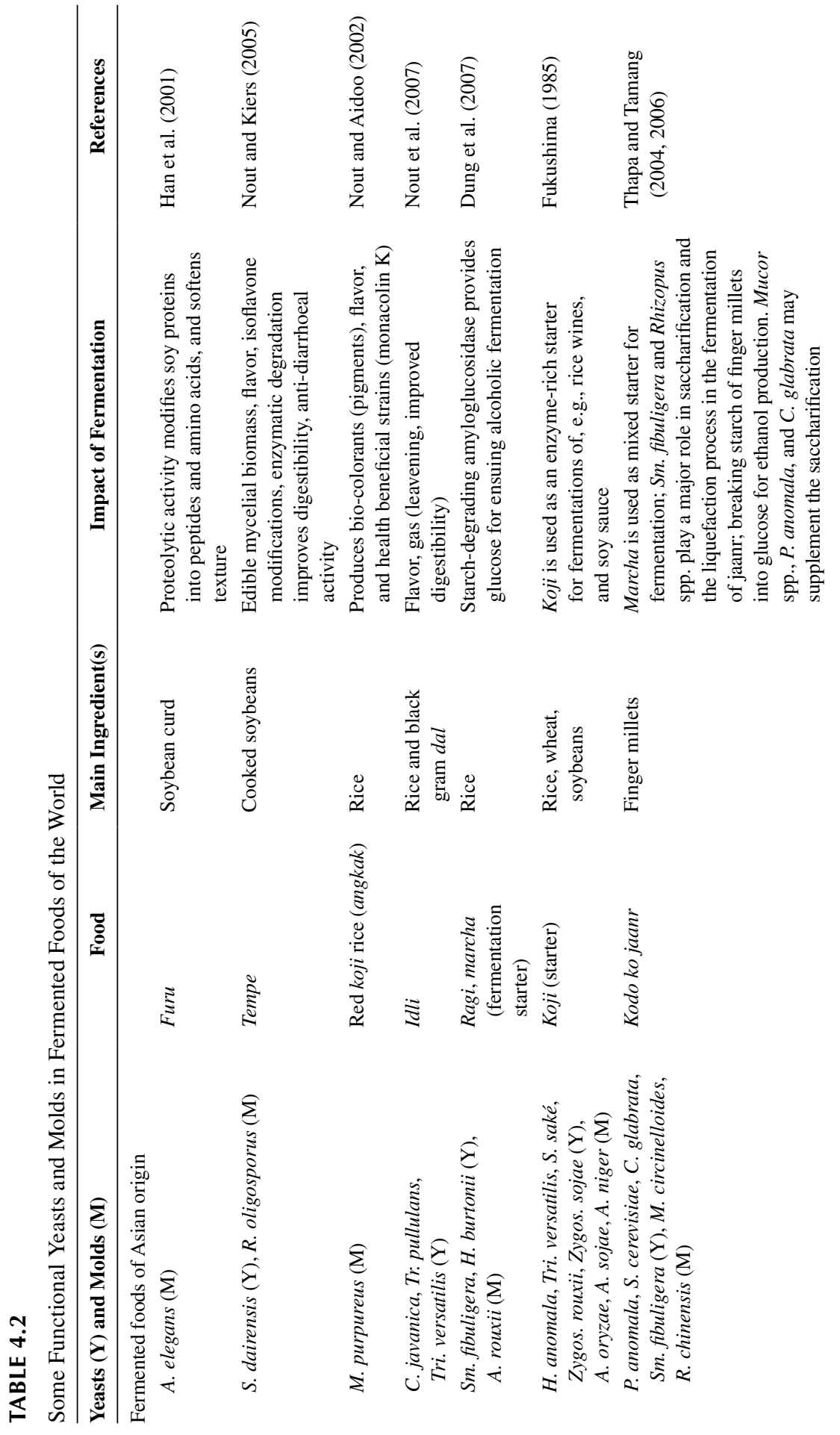



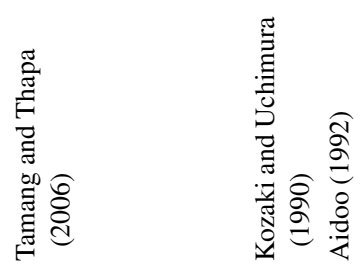

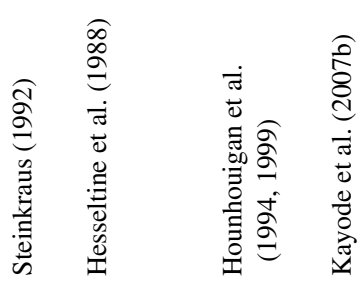
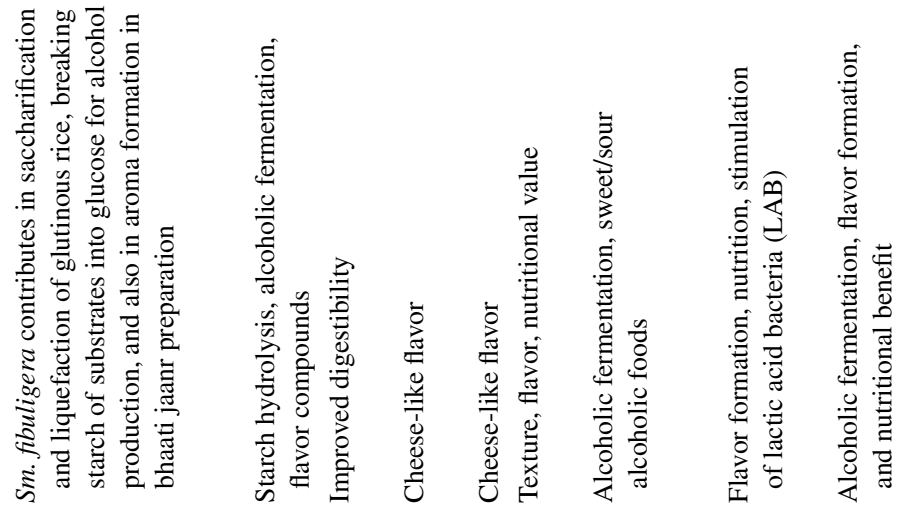

รั้

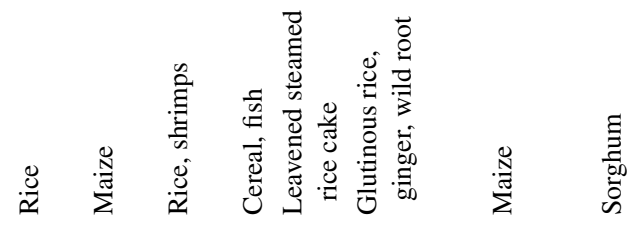

$\frac{\sqrt{3}}{3}$

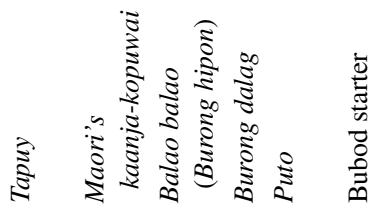

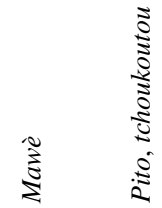
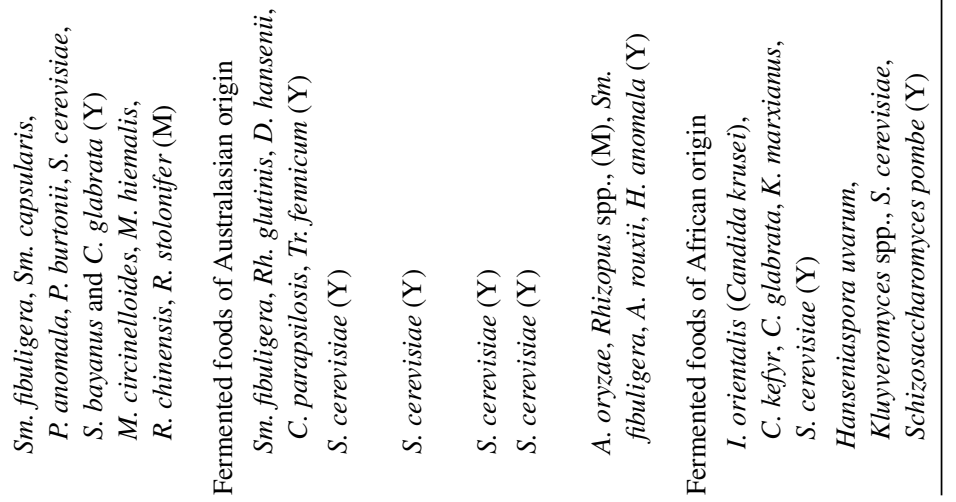


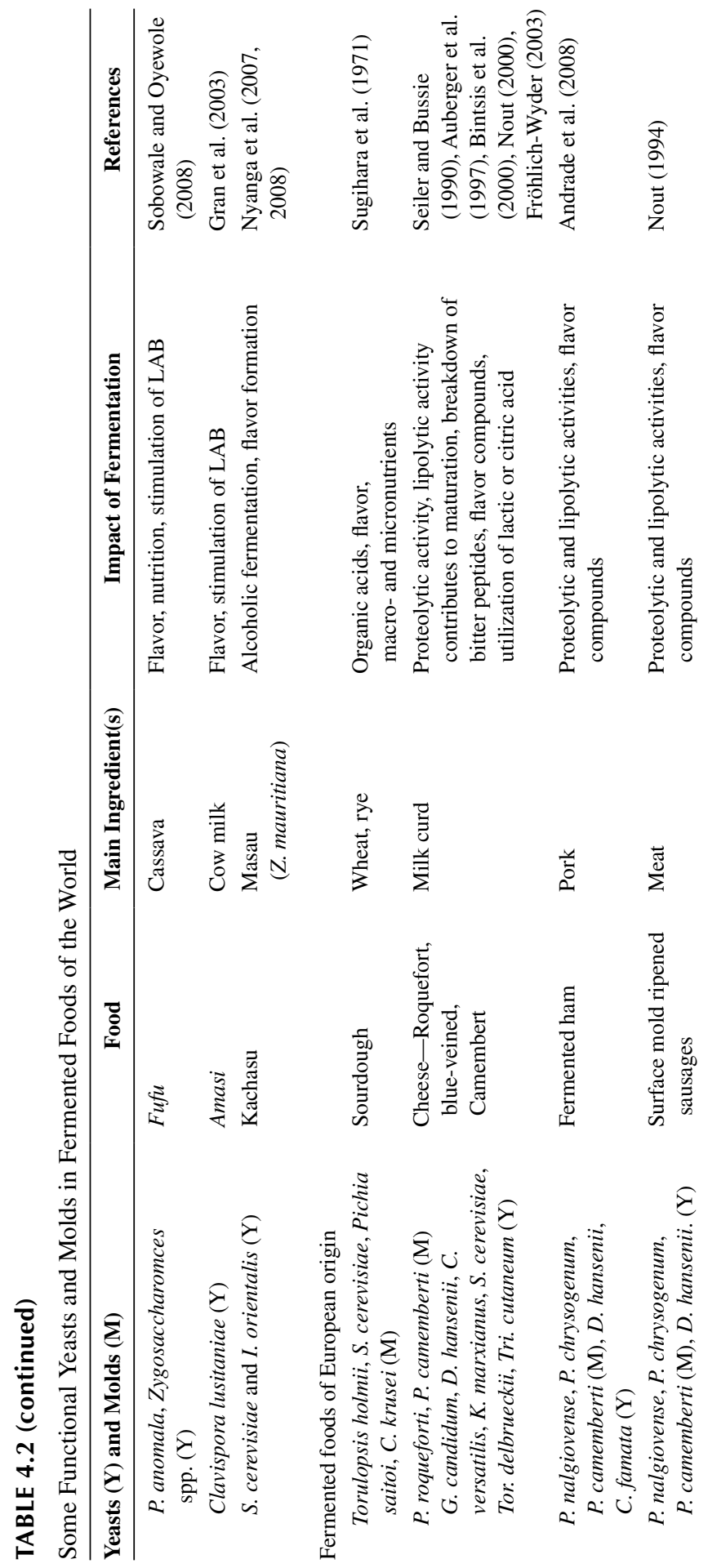




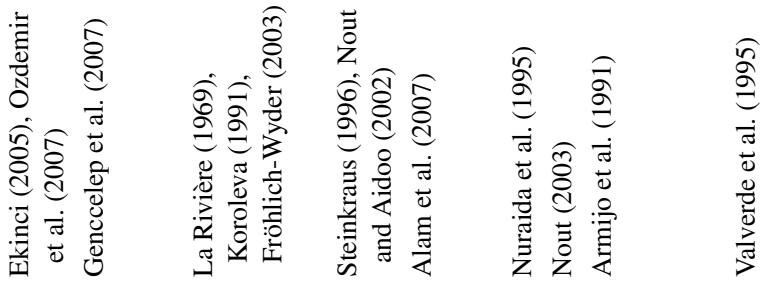

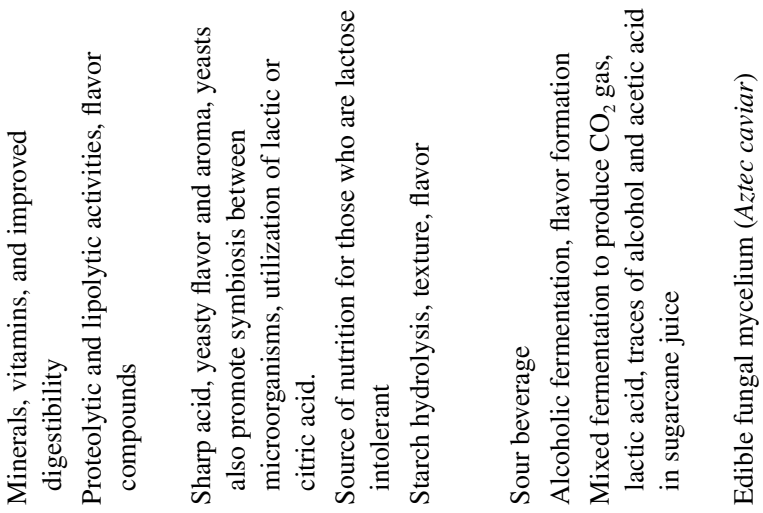

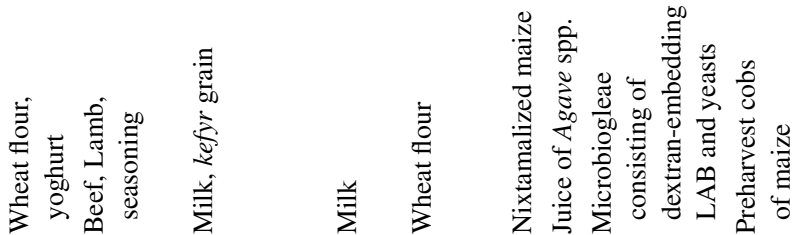

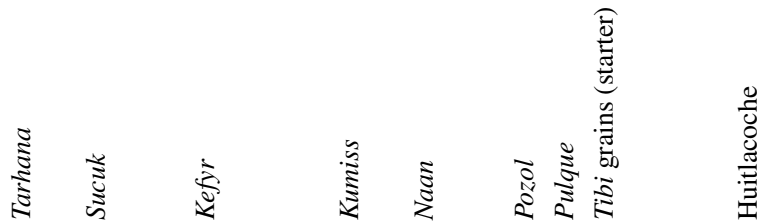
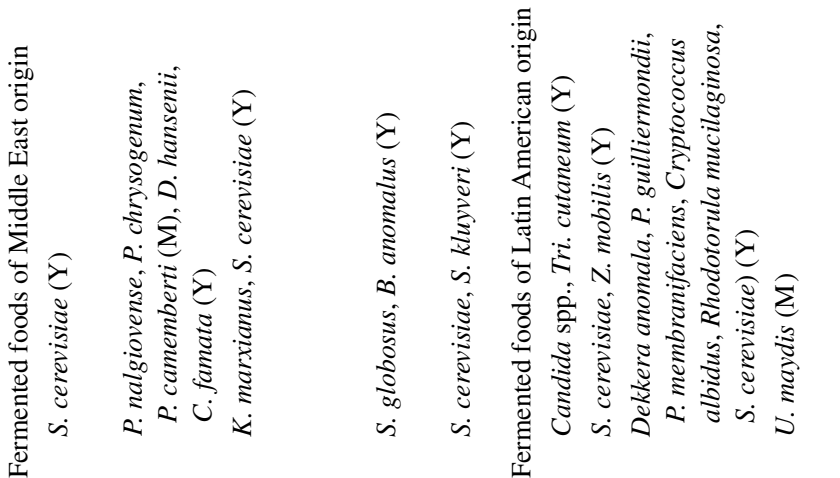


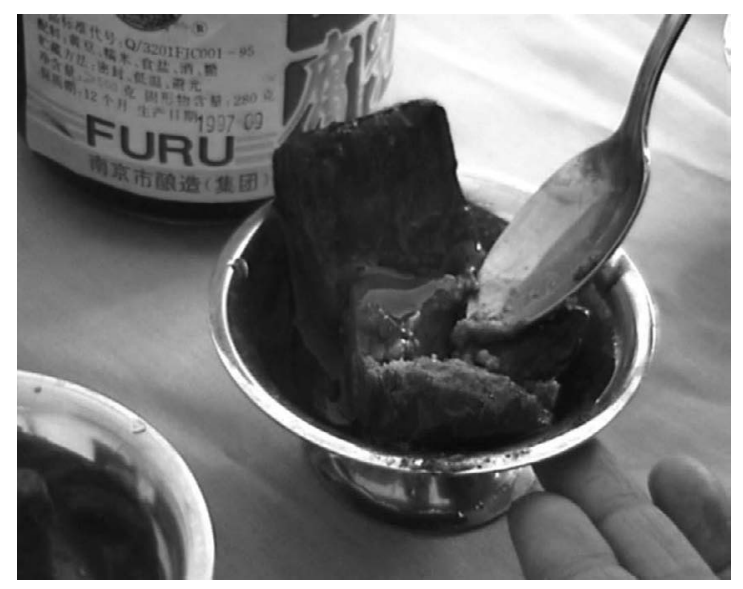

FIGURE 4.1 Furu. (From Nout, M.J.R. and Aidoo, K.E., The Mycota, eds. Osiewacz, H.D., Springer-Verlag, New York, pp. 23-47, 2002. With permission.)

\subsubsection{Idli}

$I d l i$ is a small spongy cake obtained by steaming a naturally fermented mixed batter of parboiled rice (Oryza sativa) and black gram (Phaseolus mungo) (Figure 4.2). Idli is a popular food in South India and Sri Lanka, well appreciated for its pleasant acidic flavor and its easy digestibility. Although the batter undergoes a natural fermentation, usually a small portion of previously fermented batter (back-slop) is added to achieve better results. The fermentation takes place at ambient temperatures $\left(25^{\circ} \mathrm{C}-35^{\circ} \mathrm{C}\right)$ for 16-24h. Obligate heterofermentative lactic acid bacteria (LAB) (Leuconostoc mesenteroides) and yeasts (Saccharomyces cerevisiae, Debaryomyces hansenii, Pichia anomala and Trichosporon pullulans) co-ferment the product, later followed by Trichosporon cutaneum, and finally dominated by S. cerevisiae (Aidoo et al. 2006).

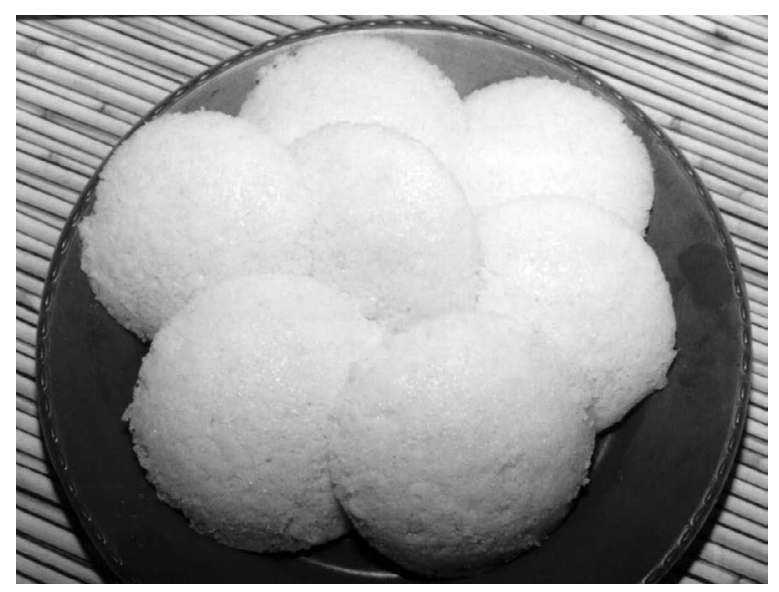

FIGURE 4.2 Idli. (Picture by Sarkar, P.K., 1998.) 
As a result of the fermentation, the $\mathrm{pH}$ decreases, amylases and proteases are formed that modify carbohydrates and degrade proteins, and considerable quantities of gas are produced. The latter cause a leavening of the batter and the final open and flexible structure of the steamed cake. Another important functional aspect of the yeasts is their contribution to the nutritional value, by enhanced vitamin B levels, and the decomposition of anti-nutrients such as phytic acid. The latter have a detrimental effect on mineral availability, and the uptake of iron is greatly enhanced in dephytinized foods (Towo et al. 2006).

\subsubsection{Ragi and Men}

Ragi (Indonesia) and men (Vietnam) are examples of amylolytic starters for rice wine preparation (Figure 4.3). Such starters principally consist of uncooked rice flour to which a local mix of herbs and spices is added. The flour and herbs are moistened with some water to form a dough, which are made into small balls or flattened discs, spread on an incubation tray, and sprinkled with previously powdered ragi or men (Dung et al. 2007). The microflora of ragi or men can now proliferate in the fresh dough during an overnight period at high relative humidity and temperatures around $30^{\circ} \mathrm{C}$. The next stage consists of a careful dehydration to stabilize and preserve the microbial starter; this is done by incubation in an artificially heated room of about $60^{\circ} \mathrm{C}$ for a few days. For commercial purposes, the tablets are packaged and labeled. Several researchers investigated the microflora of these and similar amylolytic starters. From their combined efforts, it can be generally concluded that there are three components of the microbiota. The first component comprises filamentous fungi such as Amylomyces rouxii and Rhizopus spp. that are able to degrade the native starch in the raw rice flour, by forming amylases especially amyloglucosidase, which degrades starch directly into glucose (Dung et al. 2006). The second component consists of fermentative yeasts such as Saccharomycopsis fibuligera, Hyphopichia burtonii, and S. cerevisiae; whereas some of these yeasts can degrade starch as well, their main function is in the alcoholic fermentation and the production of flavor components such as esters. The third component comprises the LAB, which do not seem to have a positive contribution to the quality of the fermented wine. However, they are present as a natural accompaniment of yeasts in the manufacture of ragi and men.

The similar mixed starters common in the Himalayas are marcha, phab, and hamei (Tamang et al. 1996, Thapa and Tamang 2004, Tamang et al. 2007), which are

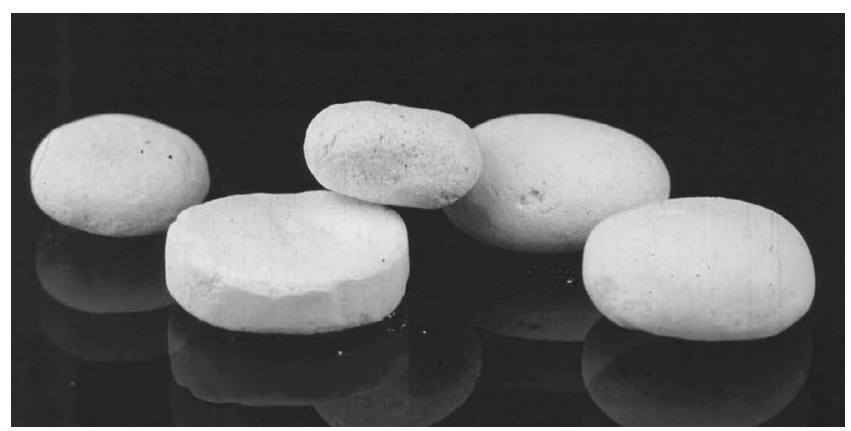

FIGURE 4.3 Ragi or men. (Picture by Nout, M.J.R., 1986.) 
used by the ethnic people to ferment alcoholic beverages and drinks. Molds, mostly species of Mucor and Rhizopus, along with the amylolytic yeast Sm. fibuligera and alcohol-producing yeasts $S$. cerevisiae and $P$. anomala are the dominant organisms in these mixed starters along with LAB, Pediococcus, and Lactobacillus (Tsuyoshi et al. 2005).

\subsubsection{Fermented Foods of Australasian Origin}

\subsubsection{Bubod}

Bubod is a dried, powdered starter used in the Philippines to prepare basi or sugarcane wine and other fermented products. Bubod starter is prepared by mixing powdered rice and ginger and then rolled and shaped into discs. These are then coated with 1-3-month old bubod, placed in bamboo baskets, and incubated at room temperature for up to $48 \mathrm{~h}$. They are sun dried to about $14 \%$ moisture. Bubod is then used to prepare an activated starter, binubudan, for the production of sugarcane wine, basi, which contains up to $14 \%$ alcohol. Bubod contains molds, yeasts, and LAB. Functional molds and yeasts in bubod include Aspergillus oryzae, Mucor, Rhizopus spp., Sm. fibuligera, A. rouxii, H. anomala, and S. cerevisiae. The molds and amylase-producing yeasts produce enzymes to release assimilable carbon compounds from the carbohydrates of the rice flour. The alcohol fermentation is dominated by $S$. cerevisiae.

\subsubsection{Puto}

Puto is a leavened steamed rice cake usually consumed for breakfast or as a snack food in the Philippines. The production of puto is an important cottage industry. It is closely related to the Indian idli except it contains no legumes and is generally served with grated coconut (Steinkraus 1996). It is made from year-old rice stock grains that are soaked and ground with water to produce slurry (galapong), which is allowed to undergo a natural fermentation. A portion of the slurry is set aside as starter culture (lebadura) that is added to the galapong. The organisms responsible for the unique characteristics of puto are heterofermentative LAB like Leuc. mesenteroides and yeasts like $S$. cerevisiae. The yeasts are usually low at the first stage of the fermentation but increase steadily during the process resulting in the production of small amounts of alcohol. S. cerevisiae also plays an important role in the leavening of the batter.

\subsubsection{Tapuy}

Tapuy is a traditional alcoholic drink popular in the mountains of northern Philippines. Tapuy is produced by inoculating cooked rice with rice yeast, bubod, and allowed to ferment in a jar in a cool place for 2 weeks. The fermented mass is then pasteurized for $30 \mathrm{~min}$ and stored for a minimum of 6 weeks; after that the clear liquor is decanted. The liquor undergoes a final pasteurization before bottling. The alcohol content reaches about $5.6 \%$ after $48 \mathrm{~h}$ and increases with fermentation. One kilogram of glutinous rice may produce about a liter of rice wine. Yeasts, molds, and LAB bring about fermentation of tapuy with yeasts as the predominant organisms. Yeasts 
isolated from tapuy include Sm. fibuligera, Rhodotorula glutinis, D. hansenii, Pichia burtonii, Candida parapsilosis, and Tr. fennicum (Sakai and Caldo 1985, Kozaki and Uchimura 1990). During the fermentation, yeasts like Sm. fibuligera and P. burtonii, which are also amylase producers, dominate the early stages. Mucor and Rhizopus spp. also produce amylolytic enzymes that hydrolyze the rice starch to sugars for conversion to alcohol. LAB, Lactobacillus viridescens and Lb. brevis, also proliferate during fermentation and contribute to the production of organic acids. In the Philippines, drinking tapuy is a part of traditional ritual.

\subsubsection{Fermented Foods of African Origin}

\subsubsection{Mawè}

Mawè is an acidic fermented maize dough popular in Bénin, West Africa; it is an intermediate product that is used to prepare a variety of beverages, porridges, and dishes (Figure 4.4). It is made by cleaning, washing, and decorticating maize kernels. The maize endosperm is ground finely by a wet-milling procedure. The wet flour is adjusted to dough consistency by the addition of water, and it is left at ambient temperatures $\left(25^{\circ} \mathrm{C}-30^{\circ} \mathrm{C}\right)$ for $2-3$ days, under a cover of polythene sheeting. During the period, a natural microbiological succession will take place of a mixed biota of LAB and yeasts. Gradually, the microflora will be dominated by a few heterofermentative LAB (e.g., Lb. fermentum) and several yeasts including Issatchenkia orientalis, C. kefyr, C. glabrata, Kluyveromyces marxianus, and $S$. cerevisiae (Hounhouigan et al. 1994). Experiments with pure culture starters showed that both LAB and yeasts derive benefit from the presence of the other microorganisms, resulting in better growth and acid production (Hounhouigan et al. 1999). The additional functionality of yeasts in cereal foods is the degradation of phytic acid, resulting in a better availability of mineral micronutrients for the consumer.

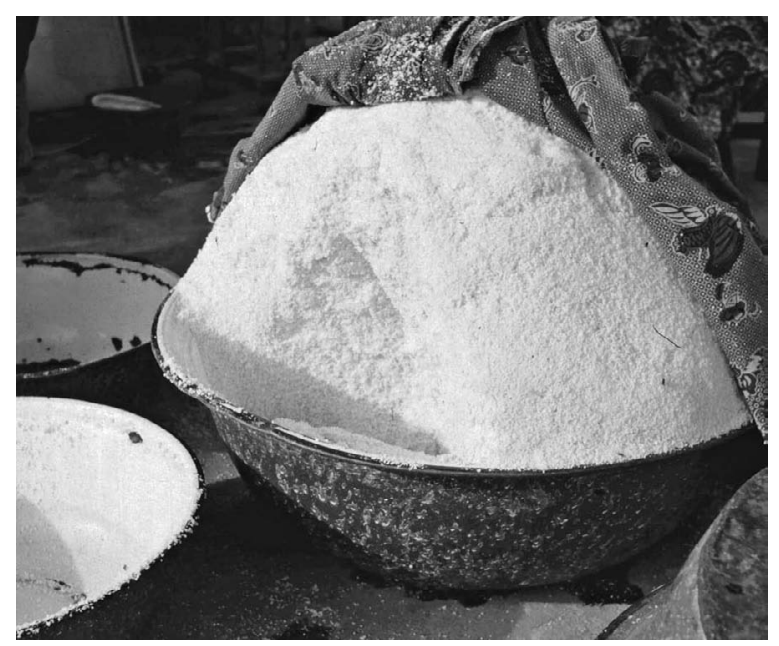

FIGURE 4.4 Mawè for sale at a market in Cotonou, Bénin. (Picture by Nout, M.J.R., 2002.) 


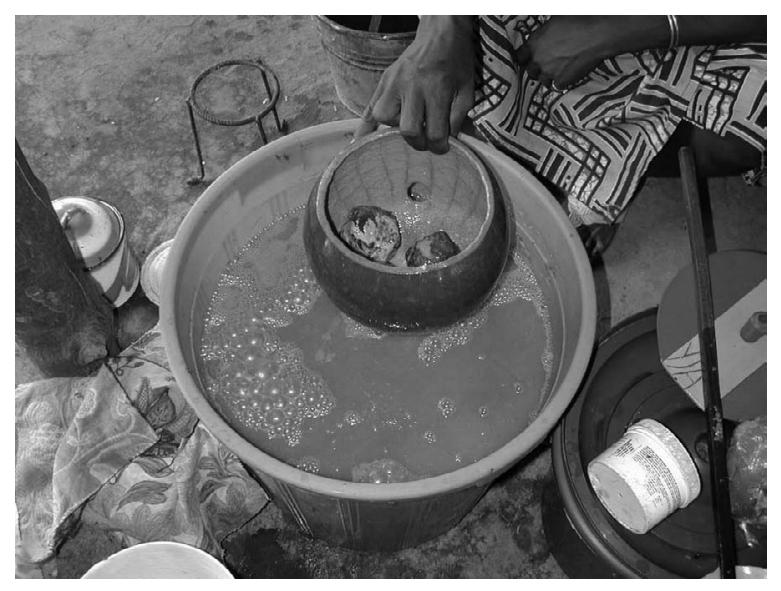

FIGURE 4.5 Tchoukoutou for sale, and calabash containing yeast starter. (Picture by Nout, M.J.R., 2006.)

\subsubsection{Tchoukoutou}

Tchoukoutou is one of the many different traditional African beers (Figure 4.5). It is made from red sorghum. First sorghum grains are cleaned, soaked, allowed to germinate (sprout) followed by a careful sun-drying in order to stabilize the obtained malt. After polishing and grinding the malt, it is mashed with water at a gradually increasing temperature until the final boiling, within a total period of 4-5h (Kayode et al. 2007b). The wort obtained is decanted, cooled, and transferred to fermentation vessels that contain active yeast sediment. Extensive research on African beer yeasts has shown that most can be identified as $S$. cerevisiae. Although different genotypic clusters can be distinguished (beer, porridge, palm wine), these are distinctly different from the $S$. cerevisiae of industrial (European) origin (Jespersen et al. 2005). The alcoholic fermentation starts immediately. After 1 day, the beer is slightly alcoholic, effervescent, and sweet. Gradually, the sweet taste is replaced by alcohol and acidity. There is always a contaminant flora of acidifying bacteria (acetic and LAB) that limit the shelf-life to only 3 days. Tchoukoutou has a relatively low (3\%-4\% v/v) alcohol content and is locally regarded as a refreshing healthy beverage, which plays an important social role during market days and other festivities. In addition to the attractive sensory attributes, it was shown that the fermentation results in very good availability of iron (Kayode et al. 2007a).

\subsubsection{Kachasu}

Kachasu is an alcoholic spirit popular in Southern Africa, particularly Zimbabwe (Figure 4.6). Wild edible fruits locally called masau (Ziziphus mauritiana) are gathered from jungles as a part of the family diet in the rural areas. The fruits are also sold at the market to generate some income. Excess fruit is allowed to undergo natural fermentation, followed by distillation into kachasu (Figure 4.6). After fermentation, the pulp contains $2.1 \%-3.7 \%$ (v/v) alcohol, whereas the alcohol content of the distillate ranges from $23.8 \%$ to $45.6 \%$ (v/v) (Nyanga et al. 2008). A study was made of 


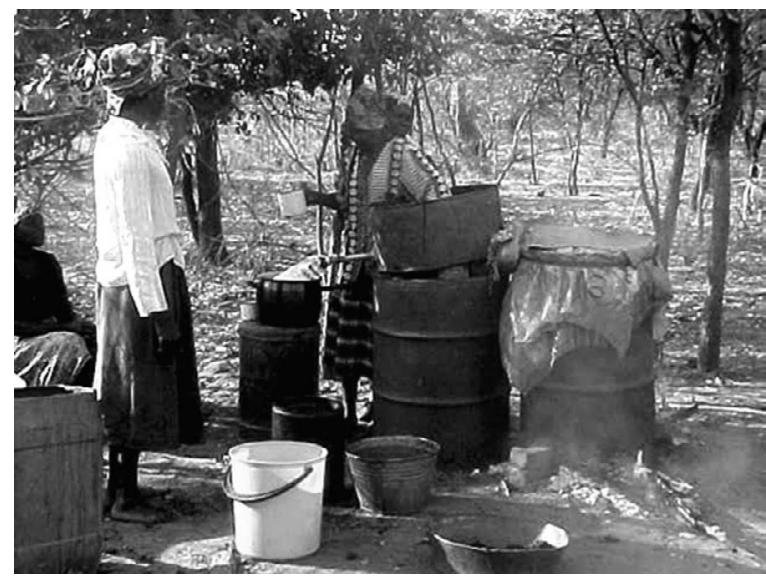

FIGURE 4.6 Kachasu: distilling in a countryside in Zimbabwe. (From Nyanga, L.K. et al., Ecol. Food Nutr., 47, 95, 2008. With permission.)

the yeasts on the fruits and during the fermentation of the fruit pulp. It was observed that the yeasts on the ripe fruit surface are dominated by Aureobasidium pullulans. This yeast was not detected anymore in the fermenting pulp which was populated by $S$. cerevisiae and I. orientalis (Nyanga et al. 2007). LAB are also encountered during this fermentation; these may stimulate yeast growth, and generate volatile flavor components.

\subsubsection{Fermented Foods of European Origin}

In this section, the roles of fungi, particularly yeasts, in the production of traditional bread, wine, beer, and other alcoholic beverages are not considered.

\subsubsection{Sourdough}

Although sourdough has a long history in Europe and North America, its origin goes back to the ancient Egyptian times. Sourdough (Figure 4.7) is a carbohydrate-based product with $\mathrm{LAB}$ and/or yeasts at low $\mathrm{pH}(<3.6)$. In bread dough, microorganisms, mainly LAB, predominate but yeasts also play a role in the development of organic acids, flavor, and nutrients. The yeasts tend to be acid tolerant and are unable to ferment maltose. It is thought that LAB benefit from yeast metabolites and the bacteria produce antimicrobial compounds for which yeasts are immune. In sourdough fermentation, the fermenting mass may be seeded with starter from previous batches and maintained at $20^{\circ} \mathrm{C}-30^{\circ} \mathrm{C}$. Where such fermentation is propagated continuously, the microorganisms are usually heterofermentative, with the yeast $C$. milleri and Lactobacillus sanfranciscensis as predominant organisms. During fermentation, the lactobacilli produce maltose phosphorylase that hydrolyses maltose to glucose as a substrate for yeast. Lactobacilli also was reported to produce the antibiotic cycloheximide in the fermenting mass to which the yeast $C$. milleri is resistant (Sugihara et al. 1971). Wagner (2005) published on the production of sourdough bread to illustrate the role of industrial microorganisms in the food industry. 


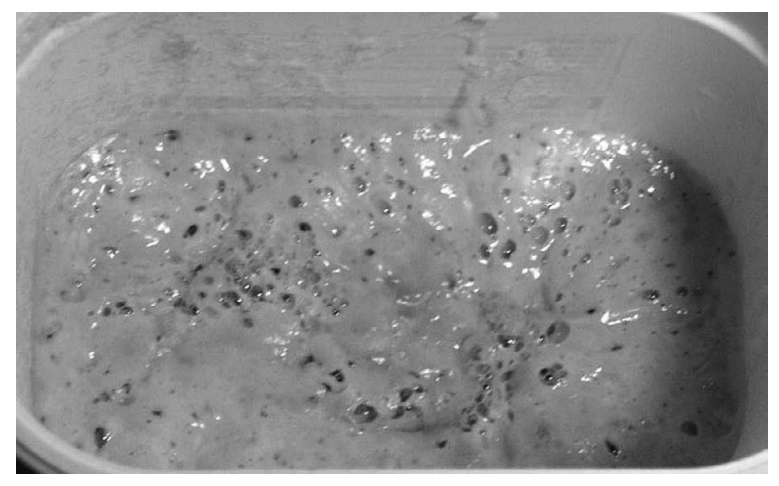

FIGURE 4.7 Sourdough. (From http://en.wikipedia.org/wiki/File:masa_madre.jpg, accessed March 20, 2009.)

\subsubsection{Cheese}

Mold-ripened cheeses are usually dominated by Penicillium spp. (Samson 1993). Camembert cheese is an example of a surface-ripened cheese with the mold P. camemberti. The cheese curd is sprayed with an aerosol of $P$. camemberti conidia and after brining and conditioning, the mold starts to develop at the surface during the incubation period. The starter strains have colors ranging from white to grayish blue and during ripening, lipolytic and proteolytic enzymes are produced by the mold that then diffuse into the cheese resulting in softening and the development of flavor. The product is ready for consumption in 3-5 weeks (Kosikowski 1997). Like molds, yeasts also play an important role in surface-ripened cheeses during maturation and develop a smear of growth on the surface that results in the development of flavor. The smear is a biomass of yeasts and bacteria, and the main yeasts species are Trichosporon spp., Y. lipolytica, K. lactis, and Candida spp. (Bockelmann and Hoppe-Seyler 2001, Petersen et al. 2002, Hansen and Jakobsen 2004).

\subsubsection{Fermented Meats}

In Europe, fermented meat products date back to Roman times and production spread to other European countries and the rest of the world; Europe is still a major producer and consumer of fermented dry sausages. LAB, molds, and yeasts all contribute to the development of the characteristic flavor and aroma of fermented meat and sausages. Molds, in particular Penicillium spp., are traditionally used as starter cultures. Aspergillus and Eurotium spp. also contribute to the fermentation and ripening of meat (Samson 1993, Josephsen and Jespersen 2004). Molds produce extracellular enzymes (amylases, proteases, lipases) and give a characteristic flavor and aroma. When carbohydrates becomes limiting in the protein-rich substrate, amino acids may be used as a carbon source. The most common molds used in mold-ripened fermented meat include Penicillium nalgiovense, $P$. chrysogenum, $P$. camembertii, and other molds include $P$. commune, $P$. aurantiogriseum, and $P$. olsonii. $P$. nalgiovense and $P$. chrysogenum are the main organisms in the production of salami. Yeasts produce proteolytic and lipolytic enzymes and help develop flavor in the fermentation of meat and meat 
products. Debaryomyces polymorphus, C. zeylanoides, P. membranifaciens, P. guilliermondii, and Cryptococcus spp. are known to be responsible for the ripening of cured ham.

\subsubsection{Fermented Foods of Middle East Origin}

\subsubsection{Tarhana}

Tarhana, a traditional Turkish fermented cereal food with sour acidic taste and yeast flavor, is produced principally by mixing wheat flour, yoghurt, yeast, vegetables (tomatoes, onions, green pepper, and paprika), salt, and spices (mint, thyme, dill, tarhana herb, etc.). S. cerevisiae and LAB (Streptococcus thermophilus, Lb. lactis, Lc. diacetylactis, Lb. bulgaricus, Lb. acidophilus, Leuc. cremoris, and Lb. casei) are the most important fermentative microorganisms. Studies on tarhana fermentation showed a significant increase in riboflavin, niacin, pantothenic acid, ascorbic acid, and folic acid contents of the product (Ekinci 2005). Ozdemir et al. (2007) reported that since tarhana is a good source of B vitamins, minerals, organic acids, and free amino acids with improved digestive properties, and since it is a product of yeast and LAB fermentation, it may be considered a functional and probiotic food. Tarhanalike products are known as trahana in Greece, kishk in Egypt, kushuk in Iraq, and tahanyaltalkuna in Hungary and Finland.

\subsubsection{Kefyr}

Kefyr is an acidic, mild alcoholic fermented milk originating from central Asia but has become very popular in the Middle East. A review on the history and the symbiotic microflora of kefyr was reported by Fröhlich-Wyder (2003). Traditionally, kefyr was prepared from bags of goat hides of cow, sheep, or goat milk inoculated with the kefyr grain. The microflora of kefyr is known to be dependent on the fermentation process employed. However, Von Wiese (1986) and Koroleva (1991) reported that $\mathrm{LAB}$ and yeasts were the main symbiotic microflora. The production of kefyr is a two-stage process, namely fermentation occurring at $18^{\circ} \mathrm{C}-22^{\circ} \mathrm{C}$ for $18-20 \mathrm{~h}$ followed by a ripening process at $8^{\circ} \mathrm{C}-10^{\circ} \mathrm{C}$ for $1-3$ days (Fröhlich-Wyder 2003). Yeasts like $K$. marxianus, C. kefyr, S. cerevisiae, and S. delbreuckii (Torulaspora delbrueckii) were isolated from kefyr (Wouters et al. 2002). On an industrial scale, addition of kefyr grains is rare; instead commercial mixed cultures isolated from the grains are used (Hansen and Jakobsen 2004).

\subsubsection{Koumiss}

Koumiss originates from Kazakhstan; it is a milk wine originally made from mare's milk; however, variants are now made from cow's milk (Figure 4.8). Koumiss usually contains about $2 \%$ alcohol and has a $\mathrm{pH}$ of about 4 . The predominant microflora of koumiss are LAB and yeasts, particularly S. unisporus and $K$. marxianus (Hansen and Jakobsen 2004). Ni et al. (2007) isolated 87 yeast strains from traditional koumiss made from mare's milk in China. They also reported the two main yeasts as S. unisporus (48.3\%) and K. marxianus (27.6\%) with $P$. membranifaciens and S. cerevisiae accounting for $15.0 \%$ and $9.1 \%$ of the total yeast isolates, respectively. 


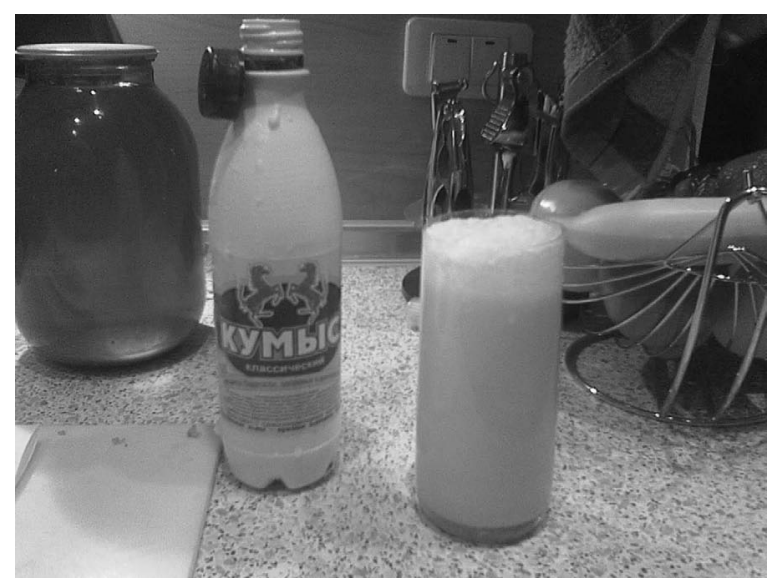

FIGURE 4.8 Koumiss. (From http://en.wikipedia.org/wiki/File:kumis.jpg, accessed March 19, 2009.)

The starter culture used in traditional koumiss was thought to contain Candida spp. and LAB (Gordon 1997). Traditional koumiss has a uniform consistency; protein from mare's milk, unlike other types of milk, does not form visible curds when renneted. Although rennet is not used to make traditional koumiss, the acid produced during fermentation results in the formation of a fine precipitate that remains in suspension.

\subsubsection{Fermented Foods of Latin American Origin}

\subsubsection{Pozol}

Pozol is a Mexican fermented maize product. Traditionally, maize grains are boiled in lime water in order to enhance the swelling and ease of decortications. This method is referred to as "nixtamalization." The cooked grains are then dehulled, washed, and ground into wet flour that can be shaped into semicylindrical balls. These balls are wrapped in polythene or in banana leaves and undergo a natural fermentation for 2-5 days. During this period a complex microbiota develops, consisting of fungi and bacteria. As a result, the $\mathrm{pH}$ decreases to 3.5-4.0, and an acidic mixed flavor is formed. Pozol balls are used to make beverages by suspending them in water with added flavors such as salt, sugar, etc. (Figure 4.9). The microflora of pozol was investigated and was dominated by LAB (Leuc. mesenteroides, Lb. plantarum, Lb. confusus, Lc. lactis, and Lc. raffinolactis), yeasts, and the filamentous fungus Geotrichum candidum (Galactomyces geotrichum) (Nuraida et al. 1995). Although the latter could not hydrolyze starch, almost all of LAB and half of the yeasts studied degraded starch. This indicates that like in ragi and men, the substrate has a big impact on the natural selection and enrichment of the niche microbiota.

\subsubsection{Pulque}

Pulque is a fermented alcoholic beverage (Figure 4.10). Mexican pulque is made from agave juice (Agave atrovirens or A. americana). Essential microorganisms in the fermentation are Lb. plantarum, a heterofermentative Leuconostoc, Zymomonas mobilis, and S. cerevisiae. Other yeasts include C. parapsilosis, C. rugosa, C. rugopelliculosa, 


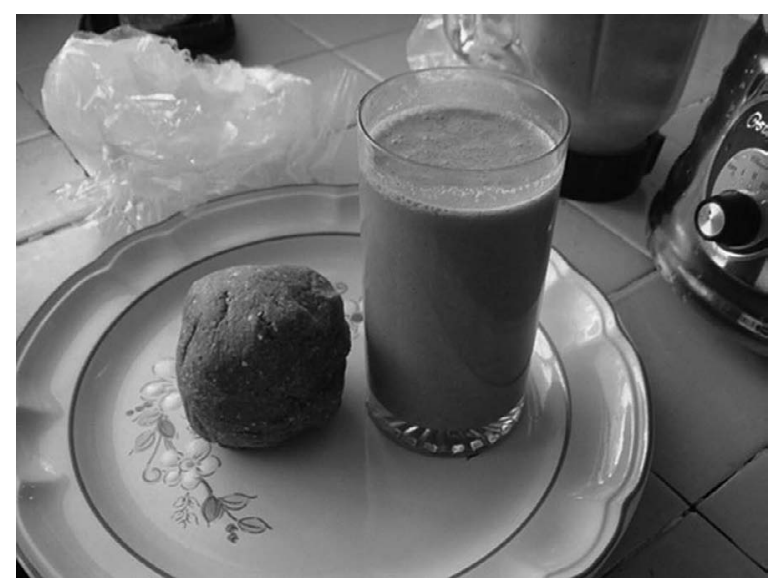

FIGURE 4.9 A pozol ball and beverage made by diluting in water. (Picture by Wacher, C.)

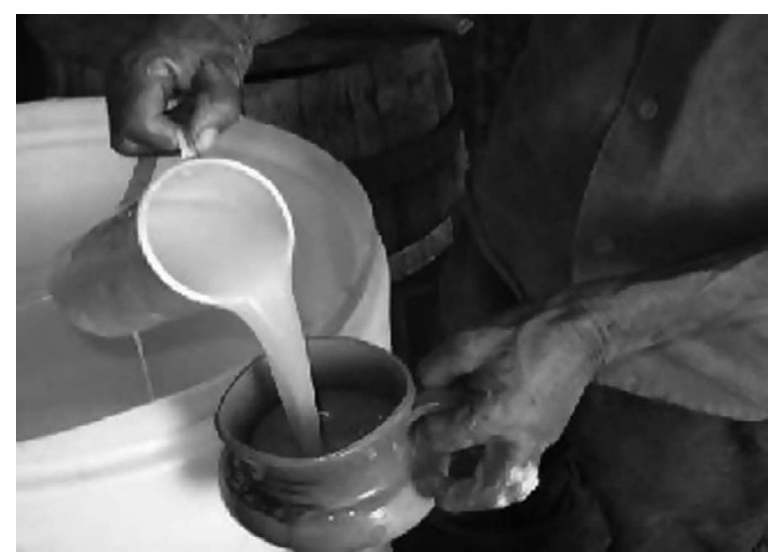

FIGURE 4.10 Pulque. (From www.ianchadwick.com/tequila/pulque.htm, accessed March 6, 2009.)

Debaryomyces carsonii, P. guilliermondii, P. membranifaciens, and Tor. delbrueckii. Although $S$. cerevisiae appears to be the major producer of ethanol, it is $Z$. mobilis that transforms $45 \%$ of the glucose to ethanol (4\%-6\% v/v in final product) and carbon dioxide (Nout 2003).

\subsubsection{Huitlacoche}

Ustilago maydis is a basidiomycete that grows as a parasite on cobs of preharvest maize (Figure 4.11). The large fruiting body is edible, and is locally known as caviar azteca, huitlacoche, or "maize mushroom" (Valverde et al. 1995). In Mexico and other Latin American countries, huitlacoche is highly regarded as an interesting dish or condiment, containing diverse nutrients such as carbohydrates, proteins, fats, vitamins, and minerals. In addition, essential amino acids (especially lysine) and fatty acids (linoleate) are present in huitlacoche. 


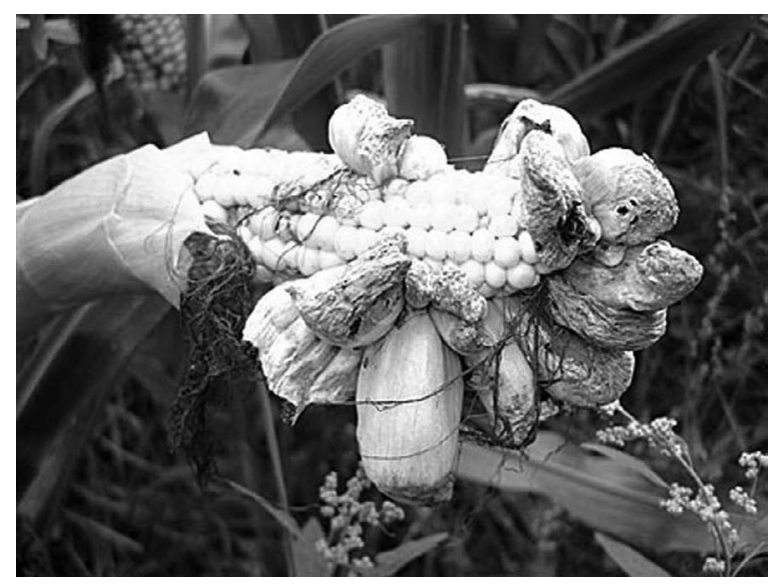

FIGURE 4.11 Huitlacoche (U. maydis) as grown on preharvest maize.

\subsection{Benefits of, and Some Problems Associated with, Fungal-Fermented Foods}

Fungal-fermented foods offer several benefits in relation to the nutrition and wellbeing of humankind. During the fermentation process, bio-enrichment of food materials occurs through a diversity of macro- and micronutrients, textures, enzymes, vitamins, trace elements, flavors, aromas, alcohols, and their derivatives. Food may also be preserved or attain an extended shelf-life through the production of alcohols, acids, esters, and other preservative compounds. The benefits of fungal-fermented foods also include improved digestibility and the production of essential nutrients, improved sensory properties, the production of edible fungal biomass (e.g., Quorn and Huitlacoche), natural food colors, carotenoids; furthermore, the processes involved in the fermentation system are usually simple.

Problems that may be associated with fungal-fermented foods include the formation of potential toxic substances, for example, ethyl carbamate produced as a result of yeast metabolism, mycotoxins (mold secondary metabolites) known to be carcinogens, yeasty off-flavors, film-forming yeasts, and undesirable discoloration. Many of the processes in fungal-fermented foods are based on solid substrate fermentation with various limitations such as mass and heat transfers, monitoring of fermentation parameters, and the relatively large inoculum size. However, the advantages of fungal-fermented foods outweigh the problems (Nout and Aidoo 2002, Nout 2003, Aidoo et al. 2006).

\subsection{Conclusion}

Yeasts and molds play a major role in the fermentation of foods during which there is bio-enrichment leading to the production of proteins, vitamins, minerals, aroma, alcohols, acids, esters, and also improvements in digestibility, preservation, and 
organoleptic properties. The authors have presented some examples of fermented foods that have received much attention and are produced with a high degree of technological advancement and automation, as well as some lesser-known and lessdeveloped products. Some of the problems associated with fungal-fermented foods have also been highlighted. The majority of these fermented food products is of plant origin and could fulfill the ever-increasing worldwide demand for healthy foods, naturally fermented products, protein-rich meat substitutes, and exotic foods of plant origin. Although fungal-fermented foods are now receiving more attention, further developments are necessary to scale up and/or improve some of the lesser-known products to maximize substrate utilization, process control, yields, and hygiene.

\section{REFERENCES}

Aidoo, K.E. 1992. Lesser-known fermented plant foods. In Applications of Biotechnology to Traditional Fermented Foods. Washington, DC: Office of International Affairs. National Research Council.

Aidoo, K.E., M.J.R. Nout, and P.K. Sarkar. 2006. Occurrence and function of yeasts in Asian indigenous fermented foods. FEMS Yeast Research 6: 30-39.

Alam, S., H.U. Shah, S. Saleemullah, and A. Riaz. 2007. Comparative studies on storage stability of ferrous iron in whole wheat flour and flat bread (naan). International Journal of Food Sciences and Nutrition 58: 54-62.

Andrade, M.J., J.J. Cordoba, B. Sanchez, E.M. Casado, and M. Rodriguez. 2008. Evaluation and selection of yeasts isolated from dry-cured Iberian ham by their volatile compound production. Food Chemistry 113: 457-463.

Armijo, C., J. Taboada, P. Lappe, and M. Ulloa. 1991. Products of fermentation by tibicos and associated yeasts. Revista Latinoamericana de Microbiologia 33: 17-23.

Auberger, B., J. Lenoir, and J.L. Bergerie. 1997. Partial characterisation of exopeptidases produced by a strain of Geotrichum candidium. Science des Aliments 17: 655-670.

Bintsis, T., E. Litopoulou-Tzanetaki, R. Davies, and R.K. Robinson. 2000. Microbiology of brines used to mature feta cheese. International Journal of Dairy Technology 53: $106-114$.

Bockelmann, W. and T. Hoppe-Seyler. 2001. The surface flora of bacterial smear-ripened cheeses from cow's and goat's milk. International Dairy Journal 11: 307-314.

Dung, N.T.P., F.M. Rombouts, and M.J.R. Nout. 2006. Functionality of selected strains of moulds and yeasts from Vietnamese rice wine starters. Food Microbiology 23: 331-340.

Dung, N.T.P., F.M. Rombouts, and M.J.R. Nout. 2007. Characteristics of some traditional Vietnamese starch-based rice wine starters (men). LWT-Food Science and Technology 40: 130-135.

Ekinci, R. 2005. The effect of fermentation and drying on the water-soluble vitamin content of tarhana, a traditional Turkish cereal food. Food Chemistry 90: 127-132.

Fröhlich-Wyder, M.T. 2003. Yeasts in dairy products. In Yeasts in Foods: Beneficial and Detrimental Aspects, eds. Boekhout, T. and V. Robert, pp. 209-237. Hamburg, Germany: Behr's Verlag DE.

Fukushima, D. 1985. Fermented vegetable protein and related foods of Japan and China. Food Reviews International 1: 149-209.

Genccelep, H., G. Kaban, and M. Kaya. 2007. Effects of starter cultures and nitrite levels on formation of biogenic amines in sucuk. Meat Science 77: 424-430. 
Gordon, J. 1997. Dairy products. In Food Industries Manual, eds. Ranken, M.D., R.C. Kill, and C. Baker, pp. 75-138. New York: Springer.

Gran, H.M., H.T. Gadaga, and J.A. Narvhus. 2003. Utilization of various starter cultures in the production of amasi, a Zimbabwean naturally fermented raw milk product. International Journal of Food Microbiology 88: 19-28.

Han, B.Z., F.M. Rombouts, and M.J.R. Nout. 2001. A Chinese fermented soybean food. International Journal of Food Microbiology 65: 1-10.

Han, B.Z., Y. Ma, F.M. Rombouts, and M.J.R. Nout. 2003. Effects of temperature and relative humidity on growth and enzyme production by Actinomucor elegans and Rhizopus oligosporus during sufu pehtze preparation. Food Chemistry 81: 27-34.

Han, B.Z., F.M. Rombouts, and M.J.R. Nout. 2004. Amino acid profiles of sufu, a Chinese fermented soybean food. Journal of Food Composition and Analysis 17: 689-698.

Hansen, T.K. and M. Jakobsen. 2004. Yeast in the dairy industry. In Fungal Biotechnology in Agricultural, Food and Environmental Applications, eds. Arora, D.K., P.D. Bridge, and D. Bhatnagar, pp. 269-279. New York: CRC Press.

Hesseltine, C.W. 1983. Microbiology of oriental fermented foods. Annual Reviews of Microbiology 37: 575-601.

Hesseltine, C.W. 1991. Zygomycetes in food fermentations. Mycologist 5: 162-169.

Hesseltine, C.W., R. Rogers, and F.G. Winarno. 1988. Microbiological studies on amylolytic oriental fermentation starters. Mycopathologia 101: 141-155.

Hounhouigan, D.J., M.J.R. Nout, C.M. Nago, J.H. Houben, and F.M. Rombouts. 1994. Microbiological changes in mawe during natural fermentation. World Journal of Microbiology and Biotechnology 10: 410-413.

Hounhouigan, D.J., M.J.R. Nout, C.M. Nago, J.H. Houben, and F.M. Rombouts. 1999. Use of starter cultures of lactobacilli and yeast in the fermentation of mawe, an African maize product. Tropical Science 39: 220-226.

Jespersen, L., D.S. Nielsen, S. Honholt, and M. Jakobsen. 2005. Occurrence and diversity of yeasts involved in fermentation of West African cocoa beans. FEMS Yeast Research 5: 441-453.

Josephsen, J. and L. Jespersen. 2004. Starter cultures and fermented products. In Handbook of Food and Beverage Fermentation Technology, eds. Hui, Y.H., L. Meunier-Goddik, and A.S. Hansen, pp. 23-50. New York: CRC Press.

Kayode, A.P.P., D.J. Hounhouigan, and M.J.R. Nout. 2007a. Impact of brewing process operations on phytate, phenolic compounds and in-vitro solubility of iron and zinc in opaque sorghum beer. LWT_Food Science and Technology 40: 834-841.

Kayode, A.P.P., D.J. Hounhouigan, M.J.R. Nout, and A. Niehof. 2007b. Household production of sorghum beer in Benin: Technological and socio-economical aspects. International Journal of Consumer Studies 31: 258-264.

Koroleva, N.S. 1991. Starters for fermented milks. Section 4: Kefir and Kumys Starter. International Dairy Federation (IDF) Bulletin 227: 35-40.

Kosikowski, F.V. 1997. Cheese and Fermented Milk Foods. Westport, CT: LLC (CRC).

Kozaki, M. and T. Uchimura. 1990. Micro-organisms in Chinese starter 'bubod' and rice wine 'tapuy' in the Philippines. Journal of the Brewing Society of Japan 85: 818-824.

Kurtzman, C.P. and J.W. Fell, eds. 1998. The Yeasts, a Taxonomic Study, 4th edn. Amsterdam, the Netherlands: Elsevier Science.

La Rivière, J.W.M. 1969. Ecology of yeasts in the kefir grain. Antoine van Leeuwenhoek 35 D15-D16.

Ni, H.J., Q.H. Bao, T.S. Sun, X. Chen, and H. Zhang. 2007. Identification and biodiversity of yeasts from koumiss in Xinjiang of China. Acta Mictobiologica Sinica 47: $578-582$. 
Nout, M.J.R. 1994. Fermented foods and food safety. Food Research International 27: 291-298.

Nout, M.J.R. 2000. Useful role of fungi in food processing. In Introduction to Food-And Airborne Fungi, eds. Samson, R.A., E. Hoekstra, J.C. Frisvad, and O. Filtenborg, pp. 364-374. Baarn, the Netherlands: Centraal Bureau voor Schimmelcultures.

Nout, M.J.R. 2003. Traditional fermented products from Africa, Latin America and Asia. In Yeasts in Food: Beneficial and Detrimental Aspects, eds. Boekhout, T. and V. Robert, pp. 451-473. Hamburg, Germany: B. Behr's Verlag GmbH \& Co. KG.

Nout, M.J.R. and K.E. Aidoo. 2002. Asian fungal fermented food. In The Mycota, ed. Osiewacz, H.D., pp. 23-47. New York: Springer-Verlag.

Nout, M.J.R. and J.L. Kiers. 2005. Tempe fermentation, innovation and functionality: Up-date into the 3rd millennium. Journal of Applied Microbiology 98: 789-805.

Nout, M.J.R., P.K. Sarkar, and L.R. Beuchat. 2007. Indigenous fermented foods. In Food Microbiology: Fundamentals and Frontiers, eds. Doyle, M.P. and L.R. Beuchat, pp. 817-835. Washington, DC: ASM Press.

Nuraida, L., M.C. Wacher, and J.D. Owens. 1995. Microbiology of pozol, a Mexican fermented maize dough. World Journal of Microbiology and Biotechnology 11: 567-571.

Nyanga, L.K., M.J.R. Nout, T.H. Gadaga, B. Theelen, T. Boekhout, and M.H. Zwietering. 2007. Yeasts and lactic acid bacteria microbiota from Masau (Ziziphus mauritiana) fruits and their fermented fruit pulp in Zimbabwe. International Journal of Food Microbiology 120: 159-166.

Nyanga, L.K., M.J.R. Nout, T.H. Gadaga, T. Boekhout, and M.H. Zwietering. 2008. Traditional processing of Masau fruits (Ziziphus mauritiana) in Zimbabwe. Ecology of Food and Nutrition 47: 95-107.

Ozdemir, S., D. Gocmen, and A.Y. Kumral. 2007. A traditional Turkish fermented cereal food: Tarhana. Food Reviews International 23: 107-121.

Petersen, K.M., S. Westall, and L. Jespersen. 2002. Microbial succession of Debaryomyces hansenii strains during the production of Danish surface-ripened cheeses. International Dairy Journal 85: 1-9.

Pretorius, I.S. 2000. Tailoring wine yeast for the new millennium: Novel approaches to the ancient art of winemaking. Yeast 16: 675-729.

Romano, P., A. Capace, and L. Jespersen. 2006. Taxonomic and ecological diversity of food and beverage yeasts. In The yeast Handbook-Yeasts in Food and Beverages, eds. Querol, A. and G.H. Fleet, pp. 13-53. Berlin, Heidelberg, Germany: Springer-Verlag.

Sakai, H. and G. Caldo. 1985. Microbiological and chemical changes in tapuy fermentation. Journal of Fermentation Technology 63: 11-16.

Samson, R.A. 1993. The exploitation of moulds in fermented foods. In Exploitation of Microorganisms, ed. Jones, D.G., pp. 321-341. London, U.K.: Chapman \& Hall.

Seiler, H. and M. Bussie. 1990. The yeasts of cheese brines. International Journal of Food Microbiology 11: 289-303.

Sobowale, A.O. and O.B. Oyewole. 2008. Effect of lactic acid fermentation of cassava on functional and sensory characteristics of fufu flour. Journal of Food Processing and Preservation 32: 560-570.

Steinkraus, K.H. 1992. Lactic acid fermentation. In Applications of Biotechnology to Traditional Fermented Foods, pp. 43-51. Washington, DC: Office of International Affairs. National Research Council. National Academy Council.

Steinkraus, K.H. 1996. Handbook of Indigenous Fermented Foods. New York: Marcel Dekker, Inc. 
Sugihara, T.F., L. Kline, and M.W. Miller. 1971. Microorganisms of the San Francisco sour dough bread process. Applied Microbiology 21: 456-458.

Tamang, J.P. and G.H. Fleet. 2009. Yeasts diversity in fermented foods and beverages. In Yeasts Biotechnology: Diversity and Applications, eds. Satyanarayana, T. and G. Kunze, pp. 169-198. New York: Springer.

Tamang, J.P. and S. Thapa. 2006. Fermentation dynamics during production of bhaati jaanr, a traditional fermented rice beverage of the Eastern Himalayas. Food Biotechnology 20: 251-261.

Tamang, J.P., S. Thapa, N. Tamang, and B. Rai. 1996. Indigenous fermented food beverages of Darjeeling hills and Sikkim: Process and product characterization. Journal of Hill Research 9: 401-411.

Tamang, J.P., S. Dewan, B. Tamang, A. Rai, U. Schillinger, and W.H. Holzapfel. 2007. Lactic acid bacteria in Hamei and Marcha of North East India. Indian Journal of Microbiology 47: 119-125.

Thapa, S. and J.P. Tamang. 2004. Product characterization of kodo ko jaanr: Fermented finger millet beverage of the Himalayas. Food Microbiology 21: 617-622.

Thapa, S. and J.P. Tamang. 2006. Microbiological and physico-chemical changes during fermentation of kodo ko jaanr, a traditional alcoholic beverage of the Darjeeling hills and Sikkim. Indian Journal of Microbiology 46: 333-341.

Towo, E., E. Matuschek, and U. Svanberg. 2006. Fermentation and enzyme treatment of tannin sorghum gruels: Effects on phenolic compounds, phytate and in vitro accessible iron. Food Chemistry 94: 369-376.

Tsuyoshi, N., R. Fudou, S. Yamanaka, M. Kozaki, N. Tamang, S. Thapa, and J.P. Tamang. 2005. Identification of yeast strains isolated from marcha in Sikkim, a microbial starter for amylolytic fermentation. International Journal of Food Microbiology 99: $135-146$.

Valverde, M.E., O. Paredeslopez, J.K. Pataky, and F. Guevaralara. 1995. Huitlacoche (Ustilago maydis) as a food source-Biology, composition, and production. Critical Reviews in Food Science and Nutrition 35: 191-229.

Von Wiese, W. 1986. Kefir-ein Sauermilcherzeugnis im Widerstreit zwischen Hersteller, Lebensmittelüberwachung und Verbraucher. Deutsche Milchwirtschaft 6: 227-229.

Wagner, S.C. 2005. From starter to finish: Producing sour dough breads to illustrate the use of industrial microorganisms. The American Biology Teacher 67: 96-101.

Wouters, J.T.M., E.H.E. Ayad, J. Hugenholtz, and G. Smit. 2002. Microbes from raw milk for fermented dairy products. International Dairy Journal 12: 91-109. 